\title{
PENGARUH RETURN ON EQUITY, CURRENT RATIO, UKURAN PERUSAHAAN TERHADAP DEBT TO EQUITY RATIO PADA PERUSAHAAN TRANSPORTASI YANG TERDAFTAR DI BURSA EFEK INDONESIA TAHUN 2014-2017
}

\author{
Muhammad Tri Saputro \\ muhammadtrisaputro@gmail.com \\ Universitas Ahmad Dahlan \\ Permata Dian Pratiwi \\ permata.pratiwi@mgm.uad.ac.id \\ Universitas Ahmad Dahlan
}

\begin{abstract}
ABSTRAK
The purpose of this study is to further investigate the effect of Return On Equity, Current Ratio, Company Size against Debt to Equity Ratio in the company transportation listed on the Indonesia Stock Exchange during the 2014-2017 period. That ratio used, namely Return On Equity, Current Ratio, Company Size and Debt to Equity Ratio. The method used is using panel data linear regression method. The population used in this study is a registered transportation company on the Indonesia Stock Exchange in the 2014-2017 period, published data and financial reports in full and have a positive net profit in the 2014-2017 period. Based on these criteria, the sample used in this study was 9 companies with population of 35 companies. The sampling technique uses a purposive technique sampling. Data were tested using a classic assumption test, panel data regression analysis, and test hypothesis. The results of this study indicate that Return On Equity, Current Ratio, Size The company has no significant effect on Debt to Equity Ratio.
\end{abstract}

Keywords: Return On Equity, Current Ratio, Company Size, Debt to Equity Ratio.

\begin{tabular}{l}
\hline \multicolumn{3}{c}{ PENDAHULUAN } \\
\hline Di era globalisasi saat ini \\
persaingan bisnis di berbagai sektor terus \\
meningkat, hal ini yang menyebabkan \\
timbulnya iklim persaingan yang \\
kompetitif di bidang usaha baik di sektor \\
industri maupun jasa. Adanya persaingan \\
pasar bebas menuntut perusahaan untuk \\
selalu mengembangkan strateginya agar \\
dapat bertahan hidup, berkembang dan \\
berdaya saing. Chasanah (2017) \\
mengemukakan hal tersebut merupakan \\
peluang sekaligus menjadi tantangan atau \\
ancaman bagi perusahaan bila tidak \\
mengantisipasi hal ini sebelumnya, apabila \\
perusahaan tidak bisa mengantisipasinya \\
maka perusahaan bisa terjadi jatuh \\
bangkrut. Tifani (2018) menambahkan \\
persaingan di sektor transportasi salah \\
satunya yang mengalami peningkatan
\end{tabular}

dan memberi dampak yang besar terhadap aksesibilitas transportasi dalam memacu pertumbuhan ekonomi bangsa. Perusahaan memerlukan faktorfaktor pendukung yang kuat khususnya dalam pengelolaan pembiayaan atau pendanaan yang baik guna kedepannya menunjang kinerja perusahaan.

Masalah pendanaan merupakan bagian terpenting yang berkaitan dengan kegiatan operasional perusahaan dan melibatkan banyak pihak, seperti kreditur, pemegang saham, serta pihak manajemen perusahaan itu sendiri. Pendanaan tersebut dapat berasal dari internal perusahaan yang berasal dari modal saham, laba ditahan dan cadangan sedangkan eksternal perusahaan berupa dana yang berasal dari hutang (Martono dan Agus, 2012:256). Keputusan 
pendanaan yang baik dapat dilihat dari struktur modalnya.

Struktur Modal sendiri merupakan proporsi pengguanaan utang dan ekuitas. Struktur modal menjadi fokus utama bagi perusahaan karena baik buruknya struktur modal dapat mempengaruhi kondisi keuangan perusahaan (Riyanto, 2010:296). Dalam meuwujudkan struktur yang optimal menurut Supeno (2009:93) Pemilihan struktur modal yang dilakukan oleh perusahaan, selain dipengaruhi oleh besar kecilnya biaya hutang atau modal sendiri, ada faktor lain yang secara umum dapat mempengaruhi sumber pendanaan, diantaranya seperti ukuran perusahaan, penjualan, struktur aset, pertumbuhan perusahaan, profitabilitas, pajak, sikap manajemen, leverage, likuiditas, sikap pemberi pinjaman dan flekstibilitas perusahaan. Dari beberapa faktor tersebut dalam penelitian ini hanya menggunakan beberapa faktor diantaranya yaitu profitabilitas Return On Equity (ROE), likuiditas Current Ratio (CR) dan Ukuran Perusahaan (UP).

Perusahaan menginginkan tingkat profitabilitas yang selalu tinggi. Dari profit yang ada perusahaan akan mengalokasikan kedalam bentuk laba ditahan ataupun ekspansi usaha. Perusahaan yang memiliki tingkat keuntungan yang besar cenderung memiliki hutang yang kecil. Dimana perusahaan yang memiliki profitabilitas tinggi akan mendanai kegiatan operasionalnya menggunakan sumber pendanaan internal dari pada sumber pendanaan eksternal. Hasil penelitian Lessy (2013) yang berjudul pengaruh ukuran perusahaan, likuiditas, profitabilitas dan struktur aktiva terhadap struktur modal menunjukkan hasil bahwa profitabilitas berpengaruh negatif dan signifikan terhadap struktur modal. Perusahaan yang memiliki sumber pendanaan internal yang besar cenderung menggunakan laba ditahan yang besar dari pada menambah hutang perusahaan. Karena menggunakan sumber pendanaan internal memiliki risiko yang rendah dibandingkan menggunakan sumber pendanaan eksternal.

Likuiditas adalah seberapa besar kemampuan perusahaan dalam memenuhi kewajiban jangka pendeknya. Semakin besar rasio likuiditas perusahaan berarti perusahaan memiliki internal financing yang akan cukup digunakan untuk membayar kewajiannya sehingga struktur modal juga berkurang. Perusahaan dengan tingkat likuiditas yang tinggi akan mengutamakan memilih pendanaan dengan dana internalnya. Hasil penelitian Juliantika (2016) yang berjudul pengaruh profitabilitas, ukuran perusahaan, likuiditas dan risiko bisnis terhadap struktur modal menunjukkan hasil bahwa likuiditas berpengaruh negatif dan signifikan terhadap struktur modal. Hal ini dikarenakan perusahaan dengan tingkat likuiditas tinggi akan mengurangi pendanaan eksternalnya karena sumber dana internalnya tinggi.

Ukuran perusahaan merupakan salah satu faktor yang dipertimbangkan perusahaan dalam menentukan berapa besar kebijakan atau keputusan pendanaan (struktur modal) dalam memenuhi ukuran atau besarnya aset perusahaan. Apabila perusahaan semakin besar maka semakin besar pula dana yang akan dikeluarkan, baik itu dari kebijakan hutang atau modal sendiri dalam mempertahankan atau mengembangkan perusahaan. Hasil penelitian Juliantika (2016) yang berjudul pengaruh profitabilitas, ukuran perusahaan, likuiditas dan risiko bisnis terhadap struktur modal menunjukkan hasil bahwa ukuran perusahaan berpengaruh positif dan signifikan terhadap struktur modal.

Perusahaan yang besar dengan total aktiva yang banyak akan lebih berani untuk menggunakan modal dari pinjama dari pada perusahaan yang lebih kecil karena peruahaan besar mempunyai kepercayaan lebih besar dalam mendapatkan sumber dana sehingga akan memudahkan untuk mendapatkan kredit dari pihak luar. Oleh karena itu, ukuran 
perusahaan yang besar merupakan sinyal positif bagi kreditur untuk memberikan pinjaman.

Penelitian ini dilakukan pada perusahaan transportasi yang merupakan salah satu sektor yang terdaftar di Bursa Efek Indonesia (BEI) dibagi atas transportasi darat, laut dan udara. Transportasi sebagai salah satu mata rantai jaringan distribusi barang dan mobilitas penumpang berkembang sangat dinamis, serta berperan di dalam menjalankan kegiatan perekonomian. Melihat kondisi yang demikian, perusahaan membutuhkan modal yang sangat besar dan kuat untuk mendukung finansial perusahaan, agar dapat bersaing dalam memberikan fasilitas jasa yang terbaik kepada para pelanggan. Salah satu usaha untuk memperkuat faktor internalnya adalah dengan mengelola struktur modal yang baik.

Sesuai dengan latar belakang yang telah diuraikan diatas maka dapat dirumuskan permasalahan sebagai berikut:

1. Apakah Return On Equity (ROE) berpengaruh negatif signifikan terhadap Debt to Equity Ratio (DER) pada perusahaan transportasi yang terdaftar di Bursa Efek Indonesia (BEI) ?

2. Apakah Current Ratio (CR) berpengaruh negatif signifikan terhadap Debt to Equity Ratio (DER) pada perusahaan transportasi yang terdaftar di Bursa Efek Indonesia (BEI) ?

3. Apakah Ukuran Perusahaan (UP) berpengaruh positif signifikan terhadap Debt to Equity Ratio (DER) pada perusahaan transportasi yang terdaftar di Bursa Efek Indonesia (BEI) ?

\section{REVIEW LITERATUR DAN HIPOTESIS}

\section{Teori Struktur Modal Pendekatan Tradisional}

Pendekatan tradisional mengasumsikan bahwa tingkat leverage tertentu, resiko perusahaan tidak mengalami perubahan. Sehingga baik biaya modal sendiri maupun biaya hutang relatif konstan. Namun demikian setelah leverage rasio hutang tertentu, biaya hutang dan biaya modal sendiri meningkat. Peningkatan biaya modal sendiri ini akan semakin besar bahkan akan lebih besar dari pada penurunan biaya karena penggunaan hutang yang lebih murah. Akibatnya, biaya modal rata-rata tertimbang yang pada awalnya menurun, setelah leverage tertentu akan meningkat. Sjahrial (2007:216).

\section{Asymetric Information Theory}

Menurut Sjahrial (2007:207) asymetric information adalah kondisi dimana suatu pihak memiliki informasi yang lebih banyak dari pihak lain. Karena asymetric information, manajemen perusahaan tahu lebih banyak tentang perusahaan dibanding investor di pasar modal.

\section{Trade-off Theory}

Menurut Husnan dan Eny (2012:300) Teori Trade-Off disebut sebagai teori keseimbangan yaitu menyeimbangkan komposisi hutang dan modal sendiri. Teori ini pada intinya yaitu menyeimbangkan antara manfaat dan pengorbanan yang timbul sebagai akibat penggunaan hutang. Sejauh manfaat masih besar, hutang akan ditambah. Tetapi bila pengorbanan karena menggunakan hutang sudah lebih besar maka hutang tidak lagi ditambah. Pengorbanan karena menggunakan hutang tersebut bisa dalam bentuk biaya kebangkrutan (bankrutcy cost) dan biaya keagenan (agency cost). Biaya kebangkrutan antara lain terdiri dari legal fee yaitu biaya yang harus dibayar kepada ahli hukum untuk menyelesaikan klaim dan distress price yaitu kekayaan perusahaan yang terpaksa dijual dengan harga murah sewaktu perusahaan dianggap bangkrut. Semakin besar kemungkinan terjadi kebangkrutan dan semakin besar biaya kebangkrutan, semakin tidak menarik menggunakan hutang. 


\section{Pecking Order Theory}

Teori ini menyatakan bahwa perusahaan akan lebih memilih melakukan pendanaan melalui sumber internal dahulu kemudian kekurangannya di ambilkan dari sumber eksternal. Teori yang dikemukakan oleh Husnan dan Eny (2012:324) menjelaskan keputusan pendanaan yang diambil oleh perusahaan yang berbeda dengan pemikiran teori struktur modal yang telah dibahas.

\section{Rasio Keuangan}

Menurut Kasmir (2012:104) adalah: Kegiatan membandingkan angkaangka yang ada dalam laporan keuangan dengan cara membagi satu angka dengan angka lainnya. Rasio keuangan digunakan rasio keuangan ini akan terlihat kondisi kesehatan perusahaan yang bersangkutan. Rasio keuangan menurut Harahap (2009:297) rasio keuangan adalah: Angka yang diperoleh dari hasil perbandingan dari satu pos laporan keuangan dengan pos lainnya yang mempunyai hubungan yang relevan dan signifikan. Misalnya antara utang dan modal, kas dan total asset, harga pokok produksi dan total penjualan.

\section{Struktur Modal}

Struktur modal adalah perbandingan atau imbangan pendanaan jangka panjang perusahaan yang ditunjukkan oleh perbandingan hutang jangka panjang terhadap modal sendiri (Martono dan Agus, 2012:256). Terdapat dua sumber pendanaan perusahaan yaitu pendanaan internal yang berasal dari modal saham, laba ditahan dan cadangan sedangkan eksternal perusahaan berupa dana yang berasal dari hutang. Apabila perusahaan lebih mengutamakan menggunakan sumber dari dalam perusahaan untuk memenuhi kebutuhan dananya, maka akan sangat baik bagi perusahaan tersebut karena akan mengurangi ketergantungannya terhadap pihak luar. Namun apabila perusahaan mengalami pertumbuhan yang pesat dan kebutuhan akan dana meningkat, sedangkan dana dari sumber internal telah digunakan seluruhnya, maka tidak ada pilihan lain bagi perusahaan kecuali menggunakan dana dari pihak eksternal baik itu melalui hutang maupun mengeluarkan saham baru untuk memenuhi kebutuhan dananya. Maka dari itu seorang manajer keuangan harus mampu mengoptimalkan struktur modal. Struktur modal yang optimal harus mencapai suatu keseimbangan antara risiko dan pengembalian yang memaksimalkan harga saham (Brigham dan Houston, 2001).

\section{Profitabilitas}

Menurut Munawir (2004) profitabilitas menunjukkan kemampuan perusahaan untuk menghasilkan laba selama periode tertentu. Profitabilitas adalah kemampuan perusahaan untuk menghasilkan laba dengan menggunakan sumber-sumber yang dimiliki, seperti aktiva, modal atau penjualan perusahaan (Sudana, 2015:25). Perusahaan dengan tingkat profitabilitas yang tinggi akan cenderung menggunakan hutang yang relatif rendah hal ini dikarenakan pembiayaan sebagian besar kebutuhan pendanaan perusahaan telah terpenuhi dari laba ditahan yang dimilikinya, sehingga profitabilitas menjadi salah satu faktor yang dipertimbangkan dalam penentuan struktur modal perusahaan. Dalam penelitian ini rasio profitabilitas yang digunakan adalah Return On Equity (ROE).

\section{Likuiditas}

Menurut Riyanto (2011:25) likuiditas adalah kemampuan sebuah perusahaan untuk membayar kewajiban finansial jangka pendek tepat pada waktunya. Kemampuan tersebut merupakan kemampuan perusahaan dalam melanjutkan operasionalnya ketika perusahaan tersebut diwajibkan untuk melunasi kewajibannya yang akan mengurangi dana operasionalnya. Rasio (CR) merupakan rasio anatara aktiva 
lancar terhadap kewajiban lancar. Perusahaan mampu memenuhi kewajiban keuangannya tepat pada waktunya berarti perusahaan tersebut dalam keadaan "likuid" dan dikatakan mampu memenuhi kewajiban keuangan tepat pada waktunya apabila perusahaan tersebut mempunyai alat pembayaran ataupun aktiva lancar yang lebih besar dari pada hutang lancar atau hutang jangka pendek dan sebaliknya (Munawir, 2004:31). Dalam penelitian ini rasio likuiditas yang digunakan adalah Current Ratio (CR).

\section{Ukuran Perusahaan}

Riyanto (2011:305) berpendapat bahwa ukuran perusahaan menggambarkan besar kecilnya suatu perusahaan yang ditunjukkan pada total aktiva, jumlah penjualan, rata-rata total aktiva dan ratarata penjualan. Semakin besar ukuran suatu perusahaan, maka kecenderungan menggunakan modal asing juga akan semakin besar. Hal ini disebabkan karena perusahaan besar membutuhkan dana yang besar pula untuk menunjang operasionalnya dan salah satu alternatif pemenuhannya adalah dengan modal asing apabila modal sendiri tidak mencukupi (Halim, 2007:93). Ukuran perusahaan diukur melalui total asset yang diproksikan dengan nilai logaritma natural dari total asset perusahaan (Ln Total Asset).

\section{Hasil Penelitian Terdahulu}

Dari beberapa hasil penelitian yang relevan mendukung teori yang dikemukakan diatas, maka berikut ini diantaranya yaitu:

Penelitian Juliantika (2016) yang berjudul pengaruh profitabilitas, ukuran perusahaan, likuiditas dan risiko bisnis terhadap struktur modal pada perusahaan property dan realestate menunjukan profitablitas, likuiditas (CR), risiko bisnis berpengaruh negatif dan signifikan terhadap struktur modal (DER), sedangkan ukuran perusahaan berpengaruh positif dan signifikan terhadap struktur modal (DER).

Penelitian Lessy (2016) yang berjudul pengaruh ukuran perusahaan, likuiditas, profitabilitas dan struktur aktiva terhadap struktur modal pada perusahaan manufaktur menunjukan ukuran perusahaan berpengaruh negatif dan tidak signifikan terhadap struktur modal (DER), likuiditas (CR), profitabilitas, struktur aktiva berpengaruh negatif dan signifikan terhadap struktur modal (DER).

Penelitian Ramadhani (2019) yang berjudul pengaruh likuiditas, profitabilitas, dan struktur aktiva terhadap struktur modal pada perusahaan telekomunikasi indonesia menunjukan likuiditas (CR) berpengaruh negatif dan tidak signifikan terhadap struktur modal (DER), sedangkan profitabilitas, struktur aktiva berpengaruh positif dan signifakn terhadap struktur modal (DER).

Penelitian Sari (2016) yang berjudul Pengaruh profitabilitas, likuiditas, pertumbuhan aset dan ukuran perusahaan terhadap struktur modal menunjukkan hasil bahwa profitabilitas berpengaruh negatif dan tidak signifikan terhadap struktur modal, likuiditas berpengaruh negatif dan signifikan terhadap struktur modal, sedangkan ukuran perusahaan dan pertumbuhan aset berpengaruh positif dan tidak signifikan terhadap struktur modal.

\section{Hipotesis}

H1: Return On Equity (ROE) berpengaruh negatif signifikan terhadap Debt to Equity Ratio (DER) pada perusahaan transportasi. $\mathrm{H} 2$ : Current Ratio (CR) berpengaruh negatif signifikan terhadap Debt to Equity Ratio (DER) pada perusahaan transportasi. H3 : Ukuran Perusahaan (UP) berpengaruh positif signifikan terhadap Debt to Equity Ratio (DER) pada perusahaan transportasi.

\footnotetext{
METODE PENELITIAN

Populasi dan Sampel

Populasi yang digunakan dalam penelitian ini adalah perusahaan Transportasi yang terdaftar di BEI periode 2014-2017, dengan jumlah populasi 35
} 
perusahaan. Sampel yang digunakan dalam penelitian ini sebanyak 9 perusahaan. Pengambilan sampel dalam penelitian ini dilakukan dengan menggunakan teknik purposive sampling yaitu pengambilan sampel.

\section{Jenis Sumber Data}

Jenis data yang digunakan dalam penelitian ini adalah data dokumenter yaitu jenis data yang berupa arsip yang memuat semua transaksi yang terjadi pada suatu perusahaan. Sumber data yang digunakan dalam penelitian ini adalah data sekunder dimana data yang diperoleh secara tidak langsung dari sumbernya melainkan data dapat diperoleh dari kantor, buku, dan lain-lain yang erat hubungannya dengan obyek dan tujuan penelitian. Data sekunder merupakan bukti, catatan atau laporan historis yang telah tersusun dalam arsip yang telah terpublikasi dan yang tidak terpublikasi. Data yang digunakan berupa data laporan keuangan perusahaan transportasi yang bersumber dari Bursa Efek Indonesia

\section{Teknik Pengumpulan Data}

Data dalam penelitian ini diambil dari laporan keuangan yang diterbitkan di Bursa Efek Indonesia. Metode pengumpulan data menggunakan metode dokumentasi, yaitu suatu metode pengumpulan data yang memperoleh sumber data dari media elektronik, prospektus perusahaan, sampai internet. Dalam hal ini, data laporan keuangan perusahaan transportasi diperoleh dari laporan keuangan, yang dapat diakses melalui www.idx.co.id. Penelitian ini menggunakan periode penelitian dari tahun 2014-2017

\section{Definisi Operasional}

Definisi operasional variabel merupakan variabel-variabel yang digunakan dalam penelitian ini menunjukkan masing-masing. Variabelvariabel tersebut terbagi dalam dua jenis dua variabel yaitu variabel independen dan variabel dependen. Variabel independen adalah variabel yang tidak terikat oleh faktorfaktor lain, tetapi mempunyai pengaruh terhadap variabel lain. Seperti yang dikemukakan oleh Sugiyono (2008), variabel dependen adalah variabel yang dipengaruhi atau yang menjadi akibat, karena adanya variabel bebas, sedangkan variabel independen adalah variabel yang memengaruhi atau yang menjadi sebab perubahannya atau timbulnya variabel dependen.

\section{Variabel Dependen}

Dalam penelitian ini variabel dependen yang di teliti adalah struktur modal. Proksi yang digunakan untuk mengukur struktur modal dalam penelitian ini adalah Debt to Equity Ratio (DER). Rasio ini digunakan untuk mengukur perimbangan antara kewajiban yang dimiliki perusahaan dengan modal sendiri. Semakin tinggi struktur modal, maka menunjukkan tingginya ketergantungan permodalan perusahaan terhadap pihak luar sehingga beban perusahaan semakin berat. Rumus untuk menghitung DER adalah :

$$
D E R=\frac{\text { Total Hutang }}{\text { Total Modal Sendiri }}
$$

\section{Variabel Independen \\ Return on Equity (ROE)}

Profitabilitas

merupakan

kemampuan perusahaan dalam menghasilkan laba. Profitabilitas diukur dengan menggunakan rasio return on equity (ROE) yang merupakan rasio laba yang dihasilkan dari investasi pemegang saham perusahaan. Profitabilitas digunakan untuk menilai kemampuan perusahaan dalam mencari keuntungan dan juga memberikan ukuran tingkat efektifitas manajemen suatu perusahaan. Rumus untuk menghitung ROE adalah sebagai berikut :

$$
R O E=\frac{\text { Laba bersih setelah pajak }}{\text { Ekuitas pemegang saham }} \times 100 \%
$$




\section{Current Ratio (CR)}

Likuiditas merupakan kemampuan perusahaan dalam memenuhi kewajiban jangka pendeknya. Likuiditas diukur dengan menggunakan rasio current ratio (CR). Current Ratio (CR) digunakan untuk mengukur kemampuan perusahaan memenuhi hutang jangka pendeknya dengan menggunakan aktiva lancarnya. Rumus untuk menghitung CR yaitu:

$$
C R=\frac{\text { Aset lancar }}{\text { Hutang lancar }} \times 100 \%
$$

\section{Ukuran Perusahaan (UP)}

Ukuran perusahaan dapat diartikan sebagai besar kecilnya perusahaan dilihat dari kemampuan finansial perusahaan maupun lapangan usaha28 yang dilakukannya. Ukuran perusahaan diukur dengan menggunakan logaritma natural dari total asset (Ln Total Asset).

\section{Uji Instrumen}

\section{a. Statistik Deskriptif}

Statistik Deskriptif adalah statistik yang digunakan untuk menganalisa data dengan cara mendeskripsikan atau menggambarkan data yang telah terkumpul sebagaimana adanya tanpa membuat kesimpulan yang berlaku untuk umum atau generalisasi (Sugiyono, 2009).

b. Uji Normalitas

Uji normalitas bertujuan untuk membuktikan bahwa data yang dipergunakan berdistribusi normal. Model regresi yang baik adalah distribusi data normal atau mendekati normal (Thoifah, 2015). Uji normalitas menggunakan uji Jarque-Bera dengan menggunakan bantuan progam statistik. Dasar pengambilan keputusan jika probibalitas lebih besar atau sama dengan nilai alpha yang ditentukan, yaitu 5\%, maka data dikatakan berdistribusi normal, dan sebaliknya jika probibalitas kurang 5\% maka data berdistribusi tidak normal.

\section{Teknik Analisis Data \\ Uji Normalitas}

Uji normalitas bertujuan untuk mengetahui apakah masing-masing variabel berdistribusi normal atau tidak (Ghozali, 2011:160). Uji normalitas diperlukan karena untuk melakukan pengujian-pengujian variabel lainnya dengan mengasumsikan bahwa nilai residual mengikuti distribusi normal. Data yang berdistribusi normal dapat memperkecil kemungkinan terjadinya bias. Distribusi normal merupakan model yang baik bagi data yang bersifat terus-menerus dan nilainya tergantung pada sejumlah faktor, dimana masing-masing faktor memiliki pengaruh negatif atau positif yang relatif kecil (Gujarati, 2003). Uji normalitas dilakukan dengan tujuan untuk menguji apakah dalam model regresi variabel penganggu atau residual memiliki distribusi normal. Model distribusi yang baik memiliki distribusi data normal. Analisis uji normalitas melalui uji statistik Jarque-Bera. Suatu variabel dikatakan terdistribusi normal jika nilai probabilitas Jarque-Bera lebih besar dari $\alpha$ 5\% (prob. JB > 0,05) (Kusuma dan Ismanto, 2012:27)

\section{Uji Autokorelasi}

Uji autokorelasi bertujuan untuk menguji apakah dalam model regresi linier ada korelasi antara kesalahan pengganggu pada periode $t$ dengan kesalahan pengganggu pada periode sebelumnya $\mathrm{t}-1$ (Ghozali, 2013:110).

Autokorelasi adalah hubungan antara residual satu observasi dengan observasi lainnya. Setiap data residual pada suatu observasi diharapkan saling bebas dengan observasi lainnya atau tidak mengalami autokorelasi. Autokorelasi dapat berbentuk positif dan negatif serta autokorelasi juga dapat menyebabkan terjadinya kebiasan pada kesimpulan yang diambil. Autokorelasi dapat diperiksa dengan menggunakan uji BreuschGodfrey. Uji Breusch-Godfrey ini merupakan uji yang lebih bisa memberikan 
jawaban atau kepastian dari suatu analisis autokorelasi. Jika menggunakan uji Durbin-Watson sebagai alat uji maka akan ada kemungkinan memberikan hasil "tidak ada kesimpulan" namun jika menggunakan uji Breusch-Godfrey tidak akan terjadi kesimpulan seperti itu. Berdasarkan (Kusuma dan Ismanto, 2012:33) berikut adalah ketentuan untuk dapat mengambil kesimpulan pada uji Breusch-Godfrey :

Prob. Chi Square $>0,05 \rightarrow$ Tidak Terjadi Autokorelasi

Prob. Chi Square $<0,05 \rightarrow$ Terjadi Autokorelasi

\section{Uji Heteroskedastisitas}

Uji heteroskedastisitas bertujuan untuk menguji apakah dalam model regresi terjadi ketidaksamaan varian dari residual satu pengamatan ke pengamatan yang lain (Ghozali, 2013:139). Jika varian dari residual satu pengamatan ke pengamatan lain tetap, maka disebut homoskedastisitas dan jika berbeda disebut heteroskedastisitas. Model regresi yang baik adalah tidak terjadi heteroskedastisitas.

Heteroskedastisitas adalah kondisi dimana nilai varians error untuk setiap data pengamatan tidak konstan. Salah satu asumsi dalam model regresi dengan OLS (Ordinary Least Square) adalah nilai error atau residual memiliki varians yang konstan atau homoskedastisitas. Adanya heteroskedastisitas ini mengakibatkan pengujian dengan uji t menjadi tidak valid. Terdapat beberapa metode yang dapat digunakan untuk mengidentifikasi terjadinya heteroskedastisitas salah satunya yaitu uji Breusch-Pagan-Godfrey (BPG). Berdasarkan (Kusuma dan Ismanto, 2012:39) Uji BPG ini memerlukan pengurutan dan penghilangan data. Pengambilan keputusannya sebagai berikut :

Prob. Chi Square (p-value) $>0,05 \rightarrow$ Tidak Terjadi Heteroskedastisitas

Prob. Chi Square (p-value) $<0,05 \rightarrow$ Terjadi

\section{Uji Multikolinearitas}

Uji multikolinearitas bertujuan untuk menguji apakah model regresi ditemukan adanya korelasi antar variabel bebas (independen). Model regresi yang baik seharusnya tidak terjadi korelasi diantara variabel independen. Jika variabel independen saling berkorelasi, maka variabel-variabel ini tidak ortogonal. Variabel ortogonal adalah variabel independen yang memiliki nilai korelasi antar sesama variabel independen sama dengan nol (Ghozali, 2013:105). Multikolinearitas merupakan salah satu masalah dalam analisis regresi dengan OLS, yang berarti terdapat korelasi atau hubungan yang sangat tinggi pada data majemuk karena melibatkan beberapa variabel independen. Berikut adalah salah satu cara untuk penganalisaan multikolinearitas yaitu dengan pengujian korelasi. Pada pengujian ini jika korelasi antar variabel independen terlihat terlalu besar (pada umumnya > 0,90) maka merupakan adanya gejala multikolinearitas (Kusuma dan Ismanto, 2012:50).

\section{HASIL PENELITIAN DAN PEMBAHASAN}

\section{Hasil Penelitian}

Tabel 4.1

Statistik Deskriptif

\begin{tabular}{|l|c|c|c|c|}
\hline & DER & ROE & CR & UP \\
\hline Mean & $-2,500972$ & 0,489489 & 0,232451 & 0,068021 \\
\hline Median & 0,556081 & 0,468032 & 0,226675 & 0,067989 \\
\hline Maximum & 50,49835 & 1,239963 & 0,424085 & 0,077383 \\
\hline Minimum & $-99,49916$ & 0,249294 & 0,156170 & 0,062720 \\
\hline Std. Dev. & 19,97326 & 0,213388 & 0,047010 & 0,004315 \\
\hline Observations & 36 & 36 & 36 & 36 \\
\hline
\end{tabular}

Sumber: Olah data Eviews, 2019.

Dari hasil analisis statistik deskriptif diatas diperoleh informasi bahwa jumlah observasi penelitian berjumlah. Nilai mean pada variabel Debt to Equity Ratio (DER) adalah -2,500972 median sebesar 0,556081 nilai tertinggi 50,49835 dan nilai terendah $-99,49916$. Artinya nilai Debt to 
Equity Ratio (DER) tertinggi yang dimiliki perusahaan sampel selama periode penelitian adalah sebesar 50,49835 yaitu dimiliki oleh Trans Power Marine Tbk. pada tahun 2015, sedangkan nilai Debt to Equity Ratio (DER) terendah perusahaan sampel selama periode penelitian adalah sebesar -99,49916 yang dimiliki oleh Blue Bird Tbk. pada tahun 2014.

Variabel Return On Equity (ROE) memiliki mean 0,489489, median 0,468032, nilai tertinggi 1,239963, nilai terendah 0,249294. Artinya nilai Return On Equity (ROE) tertinggi yang dimiliki perusahaan sampel selama periode penelitian adalah sebesar 1,239963 yaitu dimiliki oleh Trans Power Marine Tbk. pada tahun 2016, sedangkan nilai Return On Equity (ROE) terendah perusahaan sampel selama periode penelitian adalah sebesar 0,249294 yaitu dimiliki Cardig Aero Services Tbk. pada tahun 2014

Variabel Current Ratio (CR) memiliki mean 0,232451, median 0,226675 , nilai tertinggi 0,424085 , dan nilai terendah 0,156170. Artinya nilai Current Ratio (CR) tertinggi yang dimiliki perusahaan sampel selama periode penelitian adalah sebesar 0,424085 yaitu dimiliki oleh Samudera Indonesia Tbk. pada tahun 2017, sedangkan nilai Current Ratio (CR) terendah perusahaan sampel selama periode penelitian adalah sebesar 0,156170 yaitu dimiliki oleh Pelayaran Nelly Dwi Putri Tbk. pada tahun 2017.

Variabel Ukuran Perusahaan (UP) memiliki mean 0,068021, median 0,067989 , nilai tertinggi 0,077383 , dan nilai terendah 0,062720 . Artinya nilai Ukuran Perusahaan (UP) tertinggi yang dimiliki perusahaan sampel selama periode penelitian adalah sebesar 0,077383 yaitu dimiliki oleh Pelayaran Nelly Dwi Putri Tbk. pada tahun 2016, sedangkan nilai Ukuran Perusahaan (UP) terendah perusahaan sampel selama periode penelitian adalah sebesar 0,062720 yaitu dimiliki oleh Samudera Indonesia Tbk. pada tahun 2015.

\section{Uji Asumsi Klasik Normalitas}

0,05 maka data tersebut terditribusi normal. Dalam penelitian ini diketahui data normalitas adalah sebagai berikut:

\section{Tabel 4.2}

\section{Hasil Uji Normalitas}

\begin{tabular}{|c|c|}
\hline Jarque-Bera & Probability \\
\hline 69,77887 & 0,000000 \\
\hline
\end{tabular}

Sumber: Olah data Eviews, 2019.

Hasil uji normalitas pada tabel 4.2 nilai residual dalam model regresi tidak berdistribusi normal. Hal ini ditunjukkan pada nilai prob. J-B sebesar 0,000000, yang mana lebih kecil dari 5\% $(0,000000$ $<0,05)$.

Untuk mengatasi masalah ini yaitu dengan menggunakan Logaritma Natural (LN) pada data excel di semua variabel.

Tabel 4.3

\section{Hasil Uji Normalitas}

\begin{tabular}{|c|c|}
\hline Jarque-Bera & Probability \\
\hline 5,759135 & 0,056159 \\
\hline
\end{tabular}

Sumber: Olah data Eviews, 2019.

Data diuji dengan menggunakan uji Jarque Bera. Berdasarkan hasil uji normalitas menggunakan uji Jarque Bera dilakukan perbaikan pada tabel 4.3 menunjukkan bahwa residual persamaan regresi pada uji normalitas tersebut berdistribusi normal. Hal ini ditunjukkan pada nilai prob. J-B sebesar 0,056159, yang mana lebih besar dari $5 \%(0,056159$ $>0,05)$.

\section{Autkolerasi}

Tabel 4.4

Hasil Uji Autokorelasi

\begin{tabular}{|c|c|}
\hline Prob. Chi-Square(2) & 0,0011 \\
\hline
\end{tabular}

Hasil uji B-G diatas terlihat bahwa nilai Prob. Chi-Square sebesar 0,0011 yang mana lebih kecil dari 0,05 (Prob. 
Chi-Square $<0,05)$ sehingga terkena masalah autokorelasi. Untuk memperbaiki masalah autukorelasi tersebut yaitu dengan melakukan transformasi dalam bentuk invers yaitu mengubah data dalam bentuk invers atau kuadratik.

Tabel 4.5

Hasil Uji Autokorelasi

\begin{tabular}{|c|c|}
\hline Prob. Chi-Square(2) & 0,7591 \\
\hline
\end{tabular}

Sumber: olah data Eviews, 2019.

Dengan melakukan transformasi data dalam bentuk invers telah dapat menghilangkan masalah autokorelasi. Berdasarkan uji B-G juga menunjukkan nilai dari Prob. Chi-Square $>0,05(0,7591>0,05)$.

\section{Uji Heteroskedastisitas}

\section{Tabel 4.6}

Hasil Uji Heteroskedastisitas

Hasil Uji Breusch Bagan Godfrey

\begin{tabular}{|c|c|l|c|}
\hline Obs*R-squared & 1,200016 & Prob. Chi-Square(3) & 0,7530 \\
\hline
\end{tabular}

Dari hasil pemeriksaan terhadap gejala heteroskedastisitas dengan uji BPG pada tabel 4.6 menunjukkan nilai probabilitas Chi-Square 0,7530 > 0,05. Maka uji heteroskedastisitas pada residual regresi tersebut menunjukkan tidak terjadi heteroskedastisitas pada model regresi dengan variabel dependen ROE, CR, dan UP terhadap variabel independen DER.

\section{Uji Multikolinearitas}

Berikut ini adalah hasil uji multikolinieritas yang telah dilakukan menggunakan uji korelasi.

Tabel 4.7

\section{Multikolinieritas}

\begin{tabular}{|c|c|c|c|}
\hline & ROE & CR & UP \\
\hline ROE & 1,000000 & 0,226690 & 0,023522 \\
\hline CR & 0,226690 & 1,000000 & $-0,402542$ \\
\hline UP & 0,023522 & $-0,402542$ & 1,000000 \\
\hline
\end{tabular}

Sumber: Olah data Eviews, 2019.

Uji multikolinieritas yang dilakukan menggunakan metode korelasi antar variable independen yaitu ROE, CR dan UP. Terlihat pada tabel 4.7 nilai korelasi antar variable independen ROE, CR, dan
UP $<90 \%$ atau 0,90 , maka menunjukkan tidak adanya gejala multikolinieritas.

\section{Uji Hipotesis}

Tabel 4.10

Hasil Uji t

\begin{tabular}{|l|r|c|l|}
\hline Variable & Coefficient & Prob. & Kesimpulan \\
\hline ROE & 7,777762 & 0,7463 & Tolak H1 \\
\hline CR & $-50,20422$ & 0,6517 & Tolak H2 \\
\hline UP & $-1002,344$ & 0,8516 & Tolak H3 \\
\hline
\end{tabular}

Sumber: olah data Eviews. 2019.

Nilai prob ROE sebesar 0,7463, koefisien regresi sebesar 7,777762, hasilnya menyatakan bahwa Return On Equity (ROE) tidak berpengaruh positif signifikan terhadap Debt to Equity Ratio (DER). Hasil analisis ini menunjukkan bahwa hipotesis pertama yang diujikan dalam penelitian ini ditolak, yang menyatakan bahwa Return On Equity (ROE) berpengaruh negatif signifikan terhadap Debt to Equity Ratio (DER).

Nilai prob CR sebesar 0,6517, koefisien regresi sebesar $-50,20422$, hasilnya menyatakan bahwa Current Ratio (CR) tidak berpengaruh negatif signifikan terhadap Debt to Equity Ratio (DER). Hasil analisis ini menunjukkan bahwa hipotesis kedua yang diujikan dalam penelitian ini ditolak,yang menyatakan bahwa Current Ratio (CR) berpengaruh negatif signifikan terhadap Debt to Equity Ratio (DER).

Nilai prob Ukuran Perusahaan (UP) sebesar 0,8516, koefisien regresi sebesar -1002,344, hasilnya menyatakan bahwa Ukuran Perusahaan (UP) tidak berpengaruh negatif signifikan terhadap Debt to Equity Ratio (DER). Hasil analisis ini menunjukkan bahwa hipotesis ketiga yang diujikan dalam penelitian ini ditolak, yang menyatakan bahwa Ukuran Perusahaan (UP) berpengaruh positif signifikan terhadap Debt to Equity Ratio (DER) 


\section{Pembahasan}

\section{Hasil Penelitian Hipotesis 1}

Hasil penelitian ini menunjukkan bahwa Return on Equity (ROE) tidak berpengaruh positif signifikan terhadap Debt to Equity Ratio (DER). Sedangkan hipotesis 1 dalam penelitian ini yaitu variabel Return on Equity (ROE) berpengaruh negatif signifikan terhadap Debt to Equity Ratio (DER) sehingga hipotesis 1 tidak terdukung. Hal ini menunjukkan bahwa DER yang tinggi pada perusahaan Transportasi yang terdaftar di BEI periode tahun 2014 2017 tidak dipengaruhi oleh besarnya nilai Return on Equity (ROE).

Hasil penelitian ini sejalan dengan penelitian Sari (2016) yang menunjukkan bahwa profitabilitas tidak berpengaruh signifikan terhadap Debt to Equity Ratio (DER). Menurut penelitian Pertiwi dan Darmayanti (2018) Kondisi ini menjelaskan bahwa perusahaan tidak memandang besar kecil jumlah profit yang dihasilkan dalam menentukan struktur modalnya karena perusahaan telah menetapkan struktur modalnya berdasarkan besarnya return dan biaya modal yang timbul karena penggunaan hutang untuk mendukung operasional perusahaan. Namun demikian, perusahaan tidak sepenuhnya mengabaikan profitabilitas, karena profitabilitas menjadi salah satu dasar penilaian kondisi perusahaan dan menunjukkan baik atau tidaknya prospek perusahaan di masa yang akan datang.

\section{Hasil Penelitian Hipotesis 2}

Hasil penelitian ini menunjukkan bahwa variabel Current Ratio (CR) tidak berpengaruh negatif signifikan terhadap Debt to Equity Ratio (DER). Sedangkan hipotesis 2 dalam penelitian ini yaitu variabel Current Ratio (CR) berpengaruh negatif signifikan terhadapDebt to Equity Ratio (DER) sehingga hipotesis 2 tidak terdukung. Hal ini menunjukkan bahwa Debt to Equity Ratio (DER) yang tinggi pada perusahaan transportasi yang terdaftar di BEI periode tahun 2014 2017 tidak dipengaruhi oleh besarnya nilai Current Ratio (CR) yang semakin rendah.

Hasil penelitian ini sejalan dengan penelitian dari Ramadhani (2019) yang menunjukkan bahwa likuiditas berpengaruh negatif dan tidak signifikan terhadap Debt to Equity Ratio (DER). Hasil penelitian Resino, Merdianto, dkk (2014) menunjukkan CR berpengaruh negatif dan tidak signifikan terhadap DER. Tidak berpengaruh signifkan Likuiditas (CR) terhadap strukutur modal (DER) disebabkan hutang lancarnya kecil, karena semakin tinggi kemampuan perusahaan dalam melunasi kewajiban-kewajiban jangka pendeknya maka hal tersebut dapat mengindikasikan perusahaan dalam keadaan sehat, dijelaskan pada pecking order theory dimana perusahaan lebih mengandalkan dana internalnya terlebih dahulu untuk pembiayaan investasi sehingga apabila kekurangan maka baru mencari pendanaan eksternalnya.

\section{Hasil Penelitian Hipotesis 3}

Hasil penelitian ini menunjukkan bahwa variabel Ukuran Perusahaan (UP) tidak berpengaruh negatif signifikan terhadap Debt to Equity Ratio (DER). Sedangkan hipotesis 3 dalam penelitian ini yaitu variabel Ukuran Perusahaan (UP) berpengaruh positif signifikan terhadap Debt to Equity Ratio (DER) sehingga hipotesis 3 tidak terdukung. Hal ini menunjukkan bahwa Debt to Equity Ratio (DER) yang tinggi pada perusahaan transportasi yang terdaftar di BEI periode tahun 2014 - 2017 tidak dipengaruhi oleh besarnya nilai Ukuran Perusahaan (UP) yang semakin tinggi.

Hasil penelitian ini sejalan dengan Lessy (2016) yang menunjukkan bahwa ukuran perusahaan berpengaruh negatif dan tidak signifikan terhadap Debt to Equity Ratio (DER). Ukuran perusahaan yang besar tidak akan meningkatkan atau menaikkan struktur 
modal (DER) yang digunakan. Ukuran perusahaan yang besar dapat diindikasikan bahwa perusahaan memiliki dana internal (laba ditahan) yang besar sehingga mampu untuk membiayai investasi dengan dana yang dihimpunnya tersebut. Putra dan Kesuma (2014). perusahaan tidak memiliki pengaruh terhadap penggunaan sumber dana eksternal, atau perusahaan besar yang memiliki akses lebih mudah ke pasar modal dibandingkan perusahaan kecil yang belum tentu dapat memperoleh dana dengan mudah di pasar modal. Resino, Syafitri dan Wijaya (2014).

\section{KESIMPULAN DAN SARAN}

\section{Kesimpulan}

Kesimpulan yang dapat diambil dari penelitian ini sebagai berikut:

1. Return On Equity (ROE) tidak berpengaruh negatif signifikan terhadap Debt to Equity Ratio (DER) pada perushaan Transportasi yang terdaftar di Bursa Efek Indonesia (BEI) tahun 2014-2017.

2. Current Ratio (CR) tidak berpengaruh negatif signifikan terhadap Debt to Equity Ratio (DER) pada perushaan Transportasi yang terdaftar di Bursa Efek Indonesia (BEI) tahun 2014-2017.

3. Ukuran Perusahaan (UP) tidak berpengaruh positif signifikan tehadap Debt to Equity Ratio (DER) pada perushaan Transportasi yang terdaftar di Bursa Efek Indonesia (BEI) tahun 2014-2017.

\section{Saran}

1. Akademisi / Ilmu Pengetahuan

Bagi peneliti yang ingin meneliti dengan topik sejenis sebaiknya memasukan varibel dependen yang lebih tepat dan sesuai dengan variabel independen, misal total hutang terhadap total aset.
2. Bagi Perusahaan

Pihak manajemen perusahaan harus mampu mengelola pembiayaan danpedanaannya agar mampu meningkatkan kualitas dan pendapatan bunga bersih perusahaan.

3. Bagi Investor

Calon investor yang akan berinvestasi sebaiknnya mempertimbangkan rasio-rasio yang dapat digunakan untuk menilai perusahaan, karena dari

rasio tersebut dapat digunakan untuk melihat efektifitas manajemen perusahaan dan mengukur tingkat pengembalian yang diharapkan atas investasi.

\section{DAFTAR PUSTAKA}

Brigham, F. E. dan F. J. Houston. 2001. Manajemen Keuangan 2. Salemba Empat. Jakarta. 2006. Dasar-Dasar Manajemen Keuangan. Edisi Kesepuluh. Salemba Empat. Jakarta.

Chasanah. N,W,S. 2017. Pengaruh Profitabilitas, Likuiditas, Ukuran Perusahaan terhadap Struktur Modal. Jurnal Ilmu dan Riset Manajemen. Vol 6.

Ghozali, Imam. 2011. Aplikasi Analisis Multivariat dengan Program IBM SPSS 21. Edisi 7. Semarang: Penerbit Universitas Diponegoro.

Ghozali, I. 2013. Aplikasi Analisis Multivariate dengan Program SPSS. Edisi Ketujuh. Badan Penerbit Universitas Diponegoro. Semarang.

Gujarati, Damodar N. 2003. Basic Econometrics, Found edition, United States: McGraw-Hill Education.

Halim, A. 2007. Manajemen Keuangan Bisnis. Ghalia Indonesia. Bogor.

Husnan, S. dan P. Eny. 2012. DasarDasar Manajemen Keuangan. Edisi 
Keenam. UPP STIM YKPN. Yogyakarta.

Juliantika, Ni Luh A. A. M. 2016. Pengaruh Profitabilitas, Ukuran Perusahaan, Likuiditas dan Risiko Bisnis terhadap Struktur Modal pada Perusahaan Property dan Realestate. Skripsi. Program Studi Manajemen. UNUD. Bali.

Kasmir. 2012. Analisis Laporan Keuangan, PT.Raja Grafindo Persada, Jakarta

Kusuma, Desta Rizky dan Ismanto Deny. 2012. Modul Praktikum Eviews. Yogyakarta.

Lessy, Devi Anggriyani. 2016. Pengaruh Ukuran Perusahaan, Likuiditas, Profitabilitas, dan Struktur Aktiva Terhadap Struktur Modal pada Perusahaan manufaktur. Skripsi. Program Studi Manajemen. Universitas Negeri Yogyakarta. Yogyakarta.

Martono dan H. Agus. 2012. Manajemen Keuangan. Edisi Kedua. Ekonisia. Yogyakarta.

Munawir. 2004. Analisa Laporan Keuangan. Edisi Empat. Liberty. Yogyakarta.

Pertiwi, Novianti Indah dan Darmayanti Ayu. 2018. Pengaruh Profitabilitas, Likuiditas, Struktur Aktiva dan Kebijakan Dividen Terhadap Struktur Modal Perusahaan Manufaktur di BEI. E-Jurnal Manajemen Unud, Vol. 7, No. 6, 2018: 3115-3143

Primantara, A. dan R. M. Dewi. 2016. Pengaruh Likuiditas, Profitabilitas, Resiko Bisnis, Ukuran Perusahaan dan Pajak Terhadap Struktur Modal. E-Journal Manajemen Universitas Udayana 5(5): 2696-2726.

Putra, Dwi Ema dan Kesuma Wijaya. 2014. Pengaruh Profitabilitas, Likuiditas, Ukuran, Pertumbuhan Terhadap Struktur Modal Industri Otomotif di BEI. Jurnal Universitas Udayana. Bali.
Ramadhani, Suci. 2019. Pengaruh Likuiditas, Profitabilitas dan Struktur Aktiva terhadap Struktur Modal pada Perusahaan Telekomunikasi Indonesia. Skripsi. Universitas Negeri Padang.

Resino, Merdianto, Syafitri Yancik, dan Wijaya Trisnadi. 2014. Pengaruh Likuiditas, Profitabilitas, Ukuran Perusahaan, dan Pertumbuhan Penjualan Terhadap Struktur Modal. Jurnal Manajemen STIE MDP. Palembang.

Riyanto, B. 2010. Dasar-Dasar Pembelanjaan Perusahaan (4th Ed). BPFE. Yogyakarta.

Riyanto, B. 2011. Dasar-Dasar Pembelanjaan Perusahaan. Edisi Keempat. BPFE. Yogyakarta.

Sari, A. N. 2016. Pengaruh Profitabilitas, Likuiditas, Pertumbuhan Aset dan Ukuran Perusahaan Terhadap Struktur Modal Perusahaan Otomotif Yang Terdaftar di Bursa Efek Indonesia. Skripsi. Program Studi Manajemen. Sekolah Tinggi Ilmu Ekonomi Indonesia Surabaya (STIESIA). Surabaya.

Sjahrial, D. 2007. Pengantar Manajemen Keuangan. Edisi Kedua. Mitra Wacana Media. Jakarta.

Sudana, I. M. 2015. Manajemen Keuangan Perusahaan. Edisi Kedua. Erlangga. Jakarta.

Sugiyono. 2008. Metode Penelitian Bisnis. Bandung: Alfabeta

Supeno, B. 2009. Analisis Faktor-Faktor yang Mempengaruhi Struktur Modal Perusahaan Sektor Makanan dan Minuman pada Bursa Efek Jakarta. Jurnal Tepak Manajemen Bisnis 1(1).

Tifani, Jenni. 2018. Analisis Faktor-Faktor Yang Mempengaruhi Struktur Modal Pada Perusahaan Sektor Transportasi Yang Terdaftar Di Bursa Efek Indonesia Periode 20122016. Skripsi. Program Studi Strata 
1 Manajemen Universitas Sumatera Utara. Medan.

Https://www.IDX.com. Diakses Tanggal

26 November 2018.Pada Pukul 21.53 WIB. 